\title{
Antioxidant effect of the guava byproduct in the diet of broilers in the starter phase
}

\author{
Maryelle Durães de Oliveira' ${ }^{1}$, Heloisa Helena de Carvalho Mello ${ }^{2}$, José Henrique Stringhini², \\ Alessandra Gimenez Mascarenhas ${ }^{2}$, Emmanuel Arnhold ${ }^{2}$, Edemilson Cardoso da Conceição ${ }^{3}$, \\ Julyana Machado da Silva Martins ${ }^{1}$, Adesvaldo José e Silva Júnior ${ }^{1}$
}

\author{
${ }^{1}$ Universidade Federal de Goiás, Programa de Pós-graduação em Zootecnia, Goiânia, GO, Brasil. \\ ${ }^{2}$ Universidade Federal de Goiás, Escola de Veterinária e Zootecnia, Departamento de Zootecnia, Goiânia, GO, Brasil. \\ ${ }^{3}$ Universidade Federal de Goiás, Faculdade de Farmácia, Goiânia, GO, Brasil.
}

\begin{abstract}
This work aimed to investigate the antioxidant capacity of the guava agroindustrial waste as a functional additive in broiler feed to improve the performance and meat quality of boilers. The experiment was conducted in a completely randomized design, consisting of four treatments and six replicates with 12 birds. Treatments included different levels of guava byproduct in the feed: $0,0.5,1.0$, and $1.5 \%$. We evaluated the performance of broilers at 7 and 21 days old. At 21 days old, two birds from each experimental unit were euthanized for intestine histologic evaluation (duodenum, jejunum, and ileum) and breast and deboned thigh samples were collected for analyzes of $\mathrm{pH}$, colorimetry ( $\mathrm{L}^{*}, \mathrm{a}^{*}$, and $\mathrm{b}^{*}$ ), and thiobarbituric reactive substances (TBARS). The use of guava byproduct in the diet at 7 days old did not affect feed intake and feed conversion of the birds. However, the body weight and weight gain increased linearly with the inclusion of the byproduct. At 21 days old, the guava byproduct did not depress the performance of birds. There was no effect of treatments on villus height, crypt depth, and villus:crypt ratio of the duodenum and jejunum of the birds. The inclusion of guava byproduct resulted in lower crypt depth and linear increase in villus:crypt ratio of the ileum. There was no significant difference in $\mathrm{pH}$ and colorimetry of the breast and thigh. With increasing inclusion of byproduct, TBARS value was reduced to $0.72 \%$, indicating greater lipid stability in thigh meat in this inclusion amount. Guava byproduct can be used as an alternative antioxidant additive in broiler feed because it does not depress the productive performance and improves thigh meat quality of boilers.
\end{abstract}

Key Words: animal-performance indexes, antioxidant, intestinal histology, meat characteristics, Psidium guajava L.

\section{Introduction}

Byproducts of fruits have contributed to the increased production of organic waste, causing many environmental problems. Thus, studies have been conducted to check the nutritional value of the waste and suggest alternatives for its use (Souza et al., 2011).

Knowing these plants and applying them in consolidated production systems, as in animal production, brings benefits to both parties, as it allows food production, conservation of regional native species, and the use of agroindustrial byproducts. In addition, there are the incessant search for substitutes for synthetic products used in animal feed, which

Received: September 22, 2016

Accepted: May 22, 2017

*Corresponding author: alegimenez09@hotmail.com

Copyright (C) 2018 Sociedade Brasileira de Zootecnia. This is an Open Access article distributed under the terms of the Creative Commons Attribution License (http://creativecommons.org/licenses/by/4.0/), which permits unrestricted use, distribution, and reproduction in any medium, provided the original work is properly cited. appear increasingly restricted by the importing countries of animal products produced in Brazil.

In this context, guava, Psidium guajava L., presents the potential to be used in broiler feed as a natural antioxidant. It has regular amount of acids, sugars, and pectin and presents tannins, flavonoids, essential oils, sesquiterpenoids alcohols, and acids triterpenoids in its constitution, which can reduce or inhibit oxidation of lipids or other molecules, preventing the spread of oxidation chain reactions (Iha et al., 2008). Nascimento et al. (2010) reported that, in lipid environment, the hydroacetonic and hydromethanolic extracts of the guava agroindustrial waste exhibit significant antioxidant action, acting efficiently in the initial stage of oxidation by blocking the reaction.

The replacement of synthetic by natural antioxidants presents advantages because they are not harmful to health. In the use of natural antioxidants, there is also an advantage in the preservationist level, as far as the food industry produce waste, which can have a beneficial target, favoring man and the environment. For example, guava undergoes processing for the production of juices, jams, pulps, and 
extracts. This fruit have skins and seeds, natural sources of antioxidants, which are often discarded rather than used. One of the byproducts generated in the guava industries is called "decanter" and consists of solid residue from the separation of the juice from the pulp. This byproduct is rich in phenolic antioxidants and is discharged by the juice industry; therefore, it can be used in animal diets.

Thus, with the high proportion of agroindustrial organic residues and the presence of guava bioactive phytochemicals, this work aimed to investigate the antioxidant capacity of the guava agroindustrial waste as a functional additive in broiler diet to improve performance and meat quality of broilers.

\section{Material and Methods}

The experiment was conducted in June and July 2014. All procedures in this study were conducted according to the Protocol registration CEUA/UFG 056/14 and approved by the Ethics Committee on the Use of Animals.

Two-hundred eighty-eight female broilers of Cobb500 strain were used. They were raised from one to 21 days old and purchased from a commercial hatchery. The birds were housed in batteries composed of galvanized wire cages with dimensions of $0.50 \times 0.40 \times 0.40 \mathrm{~m}$. Each cage was equipped with a drinking fountain and a feeder on the front.

The experimental design was completely randomized, consisting of four treatments and six replicates with 12 birds each. The birds were weighed and divided into plots with uniform weights between them. The treatments included different levels of guava byproduct in pre-starter and starter diets: $0 ; 0.5 ; 1.0$ and $1.5 \%$.

The guava byproduct was purchased from a trading company, obtained through the decanter process, which separated the juice from the pulp, generating a solid residue, which is equivalent to approximately $10 \%$ of the volume of guava pulp processed. The determination of total phenolic compounds was carried out, being $0.17 \%$ determined by spectrophotometry, and the chemical analysis of the byproduct (Table 1).

The experimental diets were isonutritive, based on corn and soybean meal, meeting the nutritional requirements of each growth stage, according to the recommendations of Rostagno et al. (2011) (Table 2). The feeding program comprised two stages: pre-starter diet (1 to 7 days old) and starter diet ( 8 to 21 days old). The guava byproduct was added to the basal diet replacing starches.
The birds received feed and water freely throughout the experimental period; the feeders were supplied with food twice a day to avoid waste. The cleaning of the drinking fountains was performed daily, as well as the exchange of water. The temperature and humidity were constantly monitored by thermometer and hygrometer, respectively, and the environment was controlled with the help of curtains and lighting management, according to the needs of the birds.

Table 1 - Chemical composition of guava byproduct

\begin{tabular}{lc}
\hline Parameter & $\mathrm{g} / \mathrm{kg}$ dry matter \\
\hline Dry matter & 941.4 \\
Mineral matter & 10.0 \\
Crude protein & 39.5 \\
Ethereal extract & 16.3 \\
Neutral detergent fiber & 761.8 \\
Acid detergent fiber & 453.2 \\
Phenol & 1.7 \\
\hline
\end{tabular}

Table 2 - Basal feed composition and nutritional values for the pre-starter (1 to 7 days old) and starter (8 to 21 days old) stages

\begin{tabular}{|c|c|c|}
\hline Item & -starter stage & Starter stage \\
\hline \multicolumn{3}{|l|}{ Ingredient ( $\mathrm{g} / \mathrm{kg}$ as fed) } \\
\hline Corn grain & 581.1 & 603.4 \\
\hline Soybean meal $45 \%$ & 346.1 & 325.5 \\
\hline Soy oil & 10.5 & 14.8 \\
\hline Dicalcium phosphate & 18.2 & 16.9 \\
\hline Limestone & 8.8 & 8.4 \\
\hline Salt & 4.8 & 4.6 \\
\hline DL-Methionine 99\% & 3.8 & 2.6 \\
\hline L-Lysine HCL & 4.0 & 2.2 \\
\hline L-Threonine & 1.7 & 0.6 \\
\hline Vitamin supplement $^{1}$ & 0.5 & 0.5 \\
\hline Mineral supplement ${ }^{2}$ & 0.5 & 0.5 \\
\hline Starch & 20.0 & 20.0 \\
\hline Total & $1,000.0$ & $1,000.0$ \\
\hline \multicolumn{3}{|l|}{ Composition } \\
\hline Metabolizable energy (kcal/kg) & 2,950 & 3,000 \\
\hline Crude protein ( $\mathrm{g} / \mathrm{kg}$ as fed) & 209.80 & 199.00 \\
\hline Calcium ( $\mathrm{g} / \mathrm{kg}$ as fed) & 8.91 & 8.39 \\
\hline Available phosphorus (g/kg as fed) & 4.48 & 4.21 \\
\hline Sodium $(\mathrm{g} / \mathrm{kg}$ as fed $)$ & 2.11 & 2.03 \\
\hline Potassium (g/kg as fed) & 8.01 & 7.70 \\
\hline Digestible lysine (g/kg as fed) & 13.16 & 11.26 \\
\hline Digestible cystine + methionine $(\mathrm{g} / \mathrm{kg}$ as fed $)$ & 9.34 & 7.99 \\
\hline Digestible threonine ( $\mathrm{g} / \mathrm{kg}$ as fed) & 8.55 & 7.32 \\
\hline \multicolumn{3}{|c|}{$\begin{array}{l}{ }^{1} \text { Vitamin supplement (composition per } \mathrm{kg} \text { of product): vitamin } \mathrm{A}, 3,125,000 \mathrm{IU} \text {; } \\
\text { vitamin D3, 550,000 IU; vitamin E, } 3,750 \mathrm{mg} \text {; vitamin } \mathrm{K} 3,625 \mathrm{mg} \text {; vitamin B1, } \\
250 \mathrm{mg} \text {; vitamin B2, } 1,125 \mathrm{mg} \text {; vitamin } \mathrm{B} 6,250 \mathrm{mg} \text {; vitamin B12, 3,750 mg; niacin, } \\
9,500 \mathrm{mg} \text {; calcium pantothenate, } 3,750 \mathrm{mg} \text {; folic acid, } 125 \mathrm{mg} \text {; DL-methionine, } \\
350,000 \mathrm{mg} \text {; choline chloride, } 150,000 \mathrm{mg} \text {; selenium, } 50 \mathrm{mg} \text {; antioxidant, } \\
2,500 \mathrm{mg} \text {; vehicle (sufficient quantity to), } 1,000 \mathrm{~g} \text {. }\end{array}$} \\
\hline \multicolumn{3}{|c|}{$\begin{array}{l}{ }^{2} \text { Mineral supplement (composition per } \mathrm{kg} \text { of product): manganese, } 150,000 \mathrm{mg} \text {; } \\
\text { zinc, } 100,000 \mathrm{mg} \text {; iron } 100,000 \mathrm{mg} \text {; copper, } 16,000 \mathrm{mg} \text {; iodine, } 1,500 \mathrm{mg} \text {. }\end{array}$} \\
\hline
\end{tabular}


Performance was evaluated at 7 and 21 days old. The birds and feed were weighed weekly and the weight of dead birds were recorded daily. The analyzed variables were average feed intake, average body weight, weight gain, and feed conversion.

At 21 days old, two birds from each experimental unit, with the average weight of the portion, were euthanized by cervical dislocation for intestine histologic evaluation. For the preparation of histological blades, segments of $2.0 \mathrm{~cm}$ of the duodenum, jejunum, and ileum were collected and fixed in $10 \%$ formaldehyde buffered for $24 \mathrm{~h}$. After fixation, they were stored in $70 \%$ ethanol, processed according to the methodology of Luna (1968), and stained with hematoxylineosin method.

The images were obtained in fivefold increase, using an optical microscope Leica DM 4000B coupled to a microcomputer. The images were analyzed with ImageJ software, with which were performed villus height and crypt depth measurements.

The quality of meat samples of breast and deboned thigh were analyzed. They were collected and placed in plastic bags and kept in cool boxes with ice for transport to the analysis laboratory, $24 \mathrm{~h}$ after slaughter.

Afterwards, the $\mathrm{pH}$ readings were made in triplicate in the ventral portion of the muscles using the portable pH meter (Brand: Testo, model 205). Colorimetry determinations $\left(\mathrm{L}^{*}, \mathrm{a}^{*}\right.$, and $\mathrm{b}^{*}$ ) were performed at three different points in the ventral portion of the muscles using a colorimeter (Brand KONICA MINOLTA, model Chroma meter CR-400).

Subsequently, the samples were vacuum-packed and kept chilled in freezer for the analysis of thiobarbituric reactive substances (TBARS). The samples were mixed homogeneously, so that $10 \mathrm{~g}$ of each could be used; the acid was added and the sample was placed in boiling water bath for $50 \mathrm{~min}$ and then read in the spectrophotometer, according to the methodology of Tarladgis et al. (1960).

After verification of the normal residue data, they were subjected to variance analysis with $5 \%$ of significance; regression was performed between the levels of inclusion of guava byproduct, through R Software program.

\section{Results}

Feed intake and feed conversion of broilers were not affected by the use of guava byproduct in the diet of 1 to 7-day olds. However, the body weight and weight gain increased linearly with the inclusion of guava byproduct $(\mathrm{P}<0.05)$ (Table 3).

At 21 days old, the guava byproduct did not affect broiler performance (Table 4). It is possible that the absence of guava byproduct effects on performance was reflecting the ideal conditions for development.

There was no effect of the use of guava byproduct on villus height, crypt depth, and villus:crypt ratio in the duodenum and jejunum of the birds (Tables 5 and 6).

The ileum villus height was not influenced by the addition of the guava byproduct in the diet, but there was a significant result for the crypt depth and villus:crypt ratio variables (Table 7).

There was no significant difference in $\mathrm{pH}$ of the breast and thigh of broilers in the starter stage, fed different levels of the guava byproduct in the diet (Tables 8 and 9).

No significant effect of guava byproduct was observed for lightness $\left(\mathrm{L}^{*}\right)$, red content $\left(\mathrm{a}^{*}\right)$, and yellow content $\left(\mathrm{b}^{*}\right)$ for breast meat (Table 8).

The $\mathrm{L}^{*}, \mathrm{a}^{*}$, and $\mathrm{b}^{*}$ values for thigh meat also did not differ (Table 9).

In addition, there was no influence of the levels of guava byproduct on the average values of TBARS in the breast meat samples (Table 10).

Table 3 - Average body weight (BW), weight gain (WG), feed intake (FI), and feed conversion (FC) of seven-day-old broilers fed diets containing guava byproduct

\begin{tabular}{|c|c|c|c|c|c|}
\hline Treatment & & $\mathrm{BW}(\mathrm{g})$ & WG (g) & FI (g) & $\mathrm{FC}(\mathrm{g} / \mathrm{g})$ \\
\hline $0 \%$ of guava byproduct & & 133.61 & 95.46 & 107.61 & 1.135 \\
\hline $0.5 \%$ of guava byproduct & & 151.58 & 113.33 & 126.95 & 1.120 \\
\hline $1.0 \%$ of guava byproduct & & 146.80 & 108.57 & 117.72 & 1.084 \\
\hline $1.5 \%$ of guava byproduct & & 147.11 & 108.86 & 121.50 & 1.115 \\
\hline CV (\%) & & 6.33 & 8.57 & 9.14 & 7.140 \\
\hline \multirow[t]{2}{*}{ P-value } & Linear & $0.032^{1}$ & $0.033^{2}$ & 0.085 & 0.529 \\
\hline & Quadratic & 0.056 & 0.056 & 0.175 & 0.459 \\
\hline
\end{tabular}

$\mathrm{CV}$ - coefficient of variation.

${ }^{1} \mathrm{y}=138.14+7.78 \mathrm{x}\left(\mathrm{R}^{2}=0.80\right)$

$2 \mathrm{y}=99.97+7.72 \mathrm{x}\left(\mathrm{R}^{2}=0.80\right)$ 
Table 4 - Average body weight (BW), weight gain (WG), feed intake (FI), and feed conversion (FC) of 21-day-old broilers fed diets containing guava byproduct

\begin{tabular}{|c|c|c|c|c|c|}
\hline Treatment & & $\mathrm{BW}(\mathrm{g})$ & WG $(\mathrm{g})$ & $\mathrm{FI}(\mathrm{g})$ & $\mathrm{FC}(\mathrm{g} / \mathrm{g})$ \\
\hline $0 \%$ of guava byproduct & & 609.12 & 570.93 & 956.33 & 1.678 \\
\hline $0.5 \%$ of guava byproduct & & 622.02 & 583.79 & 954.66 & 1.635 \\
\hline $1.0 \%$ of guava byproduct & & 612.90 & 574.65 & 946.19 & 1.648 \\
\hline CV (\%) & & 4.46 & 4.75 & 4.14 & 4.350 \\
\hline P-value & Linear & 0.923 & 0.918 & 0.124 & 0.158 \\
\hline
\end{tabular}

$\mathrm{CV}$ - coefficient of variation.

Table 5 - Villus height, crypt depth, and villus:crypt ratio of the duodenum of 21-day-old broilers fed guava byproduct

\begin{tabular}{|c|c|c|c|c|}
\hline Treatment & & Villus height $(\mu \mathrm{m})$ & Crypt depth $(\mu \mathrm{m})$ & Villus:crypt ratio \\
\hline $0 \%$ of guava byproduct & & 583.45 & 76.99 & 7.87 \\
\hline $0.5 \%$ of guava byproduct & & 587.60 & 87.45 & 7.25 \\
\hline $1.0 \%$ of guava byproduct & & 612.90 & 85.35 & 7.26 \\
\hline $\mathrm{CV}(\%)$ & & 15.21 & 23.08 & 25.17 \\
\hline P-value & Linear & 0.418 & 0.344 & 0.201 \\
\hline
\end{tabular}

$\mathrm{CV}$ - coefficient of variation.

Table 6 - Villus height, crypt depth, and villus:crypt ratio of the jejunum of 21-day-old broilers fed guava byproduct

\begin{tabular}{|c|c|c|c|c|}
\hline Treatment & & Villus height $(\mu \mathrm{m})$ & Crypt depth $(\mu \mathrm{m})$ & Villus:crypt ratio \\
\hline $0 \%$ of guava byproduct & & 402.31 & 67.96 & 6.00 \\
\hline $0.5 \%$ of guava byproduct & & 454.57 & 80.06 & 5.85 \\
\hline $1.0 \%$ of guava byproduct & & 465.20 & 61.17 & 7.62 \\
\hline $1.5 \%$ of guava byproduct & & 434.34 & 65.20 & 7.01 \\
\hline $\mathrm{CV}(\%)$ & & 12.29 & 20.75 & 20.57 \\
\hline \multirow[t]{2}{*}{ P-value } & Linear & 0.384 & 0.416 & 0.125 \\
\hline & Quadratic & 0.125 & 0.387 & 0.916 \\
\hline
\end{tabular}

$\mathrm{CV}$ - coefficient of variation.

Table 7 - Villus height, crypt depth, and villus:crypt ratio of the ileum of 21-day-old broilers fed guava byproduct

\begin{tabular}{|c|c|c|c|c|}
\hline Treatment & & Villus height $(\mu \mathrm{m})$ & Crypt depth $(\mu \mathrm{m})$ & Villus:crypt ratio \\
\hline $0 \%$ of guava byproduct & & 369.13 & 82.11 & 4.51 \\
\hline $0.5 \%$ of guava byproduct & & 332.79 & 64.48 & 5.31 \\
\hline $1.0 \%$ of guava byproduct & & 373.06 & 65.12 & 6.27 \\
\hline $1.5 \%$ of guava byproduct & & 474.84 & 61.94 & 7.11 \\
\hline $\mathrm{CV}(\%)$ & & 27.30 & 15.97 & 25.25 \\
\hline \multirow[t]{2}{*}{ P-value } & Linear & 0.504 & $0.007^{1}$ & $0.019^{2}$ \\
\hline & Quadratic & 0.477 & 0.141 & 0.203 \\
\hline
\end{tabular}

$\mathrm{CV}$ - coefficient of variation.

${ }^{1} \mathrm{y}=77.896-12.20 \mathrm{x}\left(\mathrm{R}^{2}=0.70\right)$.

${ }^{2} \mathrm{y}=4.732+1.381 \mathrm{x}\left(\mathrm{R}^{2}=0.63\right)$.

Table 8 - Colorimetry and $\mathrm{pH}$ of the breast of 21-day-old broilers fed guava byproduct

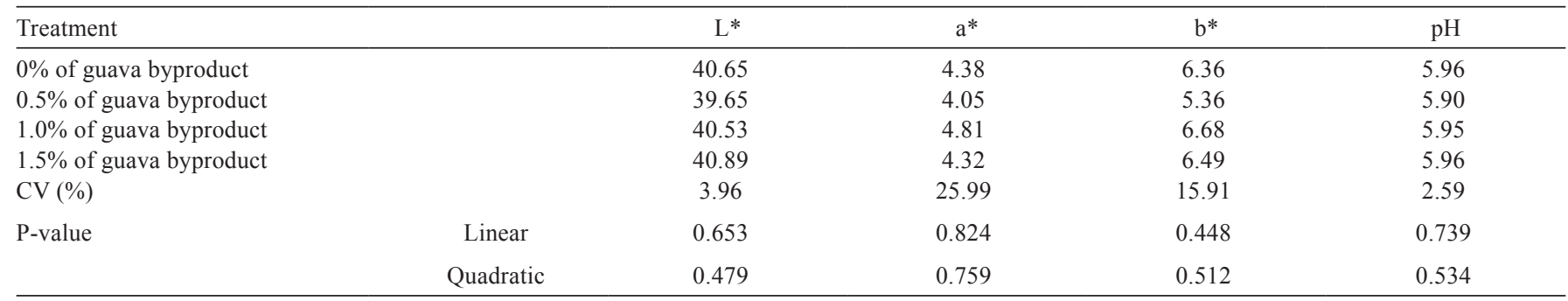

$\mathrm{L}^{*}$ - lightness; $\mathrm{a}^{*}$ - red content; $\mathrm{b}^{*}$ - yellow content.

$\mathrm{CV}$ - coefficient of variation. 
Table 9 - Colorimetry and $\mathrm{pH}$ of the thigh of 21-day-old broilers fed guava byproduct

\begin{tabular}{|c|c|c|c|c|c|}
\hline Treatment & & $\mathrm{L}^{*}$ & $\mathrm{a}^{*}$ & $\mathrm{~b}^{*}$ & $\mathrm{pH}$ \\
\hline $0 \%$ of guava byproduct & & 40.67 & 9.37 & 6.65 & 6.09 \\
\hline $0.5 \%$ of guava byproduct & & 42.22 & 9.03 & 6.30 & 6.04 \\
\hline $1.0 \%$ of guava byproduct & & 41.56 & 9.31 & 7.59 & 6.04 \\
\hline $\mathrm{CV}(\%)$ & & 3.65 & 10.87 & 11.91 & 1.47 \\
\hline P-value & Linear & 0.461 & 0.816 & 0.169 & 0.650 \\
\hline
\end{tabular}

$L^{*}$ - lightness; a* - red content; $b^{*}$ - yellow content.

$\mathrm{CV}$ - coefficient of variation.

Table 10 - Thiobarbituric reactive substances (TBARS) resulting from lipid oxidation of thigh and breast meat samples of 21-day-old broilers fed guava byproduct

\begin{tabular}{|c|c|c|c|}
\hline \multirow{2}{*}{ Treatment } & & \multicolumn{2}{|c|}{ TBARS mg/1000 g } \\
\hline & & Thigh & Breast \\
\hline $0 \%$ of guava byproduct & & 0.1775 & 0.040 \\
\hline $0.5 \%$ of guava byproduct & & 0.1324 & 0.061 \\
\hline $1.0 \%$ of guava byproduct & & 0.1333 & 0.029 \\
\hline $1.5 \%$ of guava byproduct & & 0.1108 & 0.046 \\
\hline CV $(\%)$ & & 25.10 & 27.15 \\
\hline P-value & $\begin{array}{c}\text { Linear } \\
\text { Quadratic }\end{array}$ & $\begin{array}{l}0.726 \\
0.031^{1}\end{array}$ & $\begin{array}{l}0.856 \\
0.893\end{array}$ \\
\hline
\end{tabular}

$\mathrm{CV}$ - coefficient of variation.

${ }^{1} \mathrm{y}=0.1254+0.094 \mathrm{x}-0.0657 \mathrm{x}^{2}\left(\mathrm{R}^{2}=0.39\right)$.

\section{Discussion}

The nutrient digestion and absorption capacity suffers significant adjustments in the post-hatching period and may be influenced by the feeding level and diet composition (Uni, et al, 1995; Longo et al., 2005). In this study, we could verify that, although feed intake was not affected by the addition of the byproduct in the diet, weight gain was improved.

Lira et al. (2009) evaluated the effect of including guava meal $(0,3,6,9$, and $12 \%)$ as alternative feed for broilers and found that inclusion up to the level of $12 \%$ in the diet was similar to performance and carcass yield of broilers fed without residue, as in the result of this work when using the residue as a functional additive.

The villus height and crypt depth reflect the absorption of nutrient capacity: the larger the size and amount of the villus, the greater the area of absorption of nutrients (Furlan et al. 2004). However, in this study, the addition of guava byproduct in the diets did not change the intestinal epithelium of the initial portions of the small intestine. This may be due to the absence of oxidative challenge, since the antioxidant additives are more significant to prevent oxidative losses.

The inclusion of guava byproduct in broiler diet resulted in lower crypt depth and linear increase in villus: crypt ratio. According to Kuzmuk et al. (2005), the villus height and the crypt depth are considered indicators of good development of the intestine and, under normal conditions, present a higher villus:crypt ratio, indicating that there was adequate rate of cell renewal and greater absorptive capacity.

According to Macari and Maiorka (2000), the absorption processes are dependent on mechanisms that occur in the intestinal mucosa. Trophic agents that stimulate mitotic process in the crypt-villus region stimulate the development of the mucosa; as a result, the number of cells and villus size are increased. Thus, a trophic agent provides an increase for DNA quantity because it increases the number of cells. These agents are related to ingestion and digestion of food, as well as to the chemical properties of nutrients present in the intestinal lumen.

Thus, this effect may be due to the presence of phenolic compounds in guava, giving it antioxidant properties in scavenging free radicals and suppressing the spread chain of oxidative process (Iha et al., 2008); in addition, the trophic agent promotes intestinal maturity and integrity (Yi et al., 2005). Since the higher the development of villus and crypt and its ratio, the greater the surface absorption of nutrients, better will be the broiler performance. The mucosal damage may increase the need for maintenance, providing smaller quantities of nutrients necessary for the growth of animals (Dibner and Richards, 2004).

Some studies indicate that compounds of secondary metabolism of plants used as additives can beneficially help the intestinal epithelium (Silva et al., 2010; Bona et al., 2012; Amad et al., 2013; Hashemipour et al., 2013).

The final $\mathrm{pH}$ of the meat, after $24 \mathrm{~h}$, is determining to the quality of meat because it is related to protein and meat pigments. Therefore, the value that stabilizes influences the color parameters, water holding capacity, tenderness, loss of weight by cooking, juiciness, and microbiological stability (Fletcher, 2002).

The $\mathrm{pH}$ of the breast, with the addition of guava byproduct, showed results from 5.90 to 5.96 , with no 
significant difference. These data are within the medium $\mathrm{pH}$ for chicken breast meat, which are from 5.70 to 5.96, as described by Mendes (2001) and Van Laack et al. (2000). If the $\mathrm{pH}$ is greater than 6.2 after $24 \mathrm{~h}$, the chicken meat will present high water retention, which implies a short conservation time and the establishment of dark color, characterizing the DFD (dark, firm, and dry) meat. If the $\mathrm{pH}$ is below 5.8 in less than $4 \mathrm{~h}$, there will be the PSE (pale, soft, and exudative) meat, characterized by poor water retention and the pale and soft appearance (Bridi et al., 2012).

A higher tendency to the yellow (higher $\mathrm{b}^{*}$ in relation

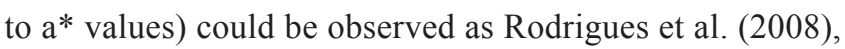
strengthening the muscle characteristics of the broiler breast compared with others such as sheep meat, for example, in which $\mathrm{L}^{*}=38,00 ; \mathrm{a}^{*}=12$ to 15 ; and $\mathrm{b}^{*}=3$ to 5 (Souza et al., 2004).

In general, the $\mathrm{pH}$ of the thigh meat was higher than the $\mathrm{pH}$ of the breast, possibly because of differences between the types of muscle fibers of each one. The dark color of the thigh and over thigh meat suggests a greater amount of type I fibers, which are aerobic; therefore, it has a lower glycolytic potential and its metabolism results in less glycogen and decreased production of lactic acid in the transformation of muscle into meat (Erickson, 2006). According to Castellini et al. (2002), the means for thigh $\mathrm{pH}$ are between 6.02 and 6.25 , which were found in this study.

Unlike the breast, the thigh meat was redder, corroborating Oliveira et al. (2015). According to Faria et al. (2009) and Warris (2010), there is a variation in the $\mathrm{pH}$ of the meat from muscles in different anatomical locations. The muscles involved in locomotor activity, such as the thigh and over thigh, for their normal biological activities (movement), generally have lower reserves of glycogen in the myocyte for post-mortem glycolysis. Thus, in these muscles, there is often less extensive acidification and higher $\mathrm{pH}$ values within $24 \mathrm{~h}$. In addition, in regions of muscles associated with locomotion, there is greater metabolic intensity and greater need for myoglobin pigment, associated with the intracellular transport of oxygen (Warris, 2010). It is noteworthy that the myoglobin is one of the most important chromogenic pigments of meat.

There was a quadratic effect of supplementation of guava byproduct on the TBARS value of the thigh meat, that is, with increasing inclusion of byproduct, the TBARS value was reduced to $0.72 \%$, indicating greater lipid stability of thigh meat in the inclusion value (Figure 1). At 21 days of

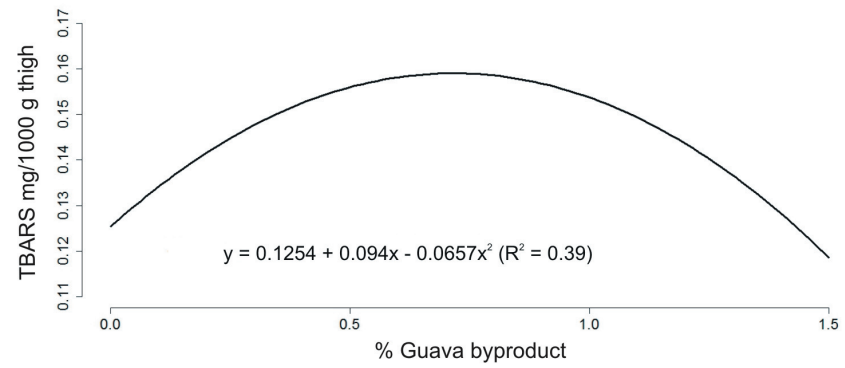

Figure 1 - Thiobarbituric reactive substances (TBARS) resulting from lipid oxidation of the thigh meat sample of 21-day-old broilers fed guava byproduct.

age, the antioxidant effect of the guava byproduct on the TBARS parameter can be verified, which means that this effect can probably act at 42 days of age at the slaughter stage.

The higher TBARS values found in the thigh meat compared with the breast meat can be explained by differences in metabolism (dark muscle) and composition. The thigh meat, or dark muscles, consists predominantly of oxidative fibers and the breast meat (white muscle) consists predominantly of glycolytic fibers (Banks, 1992). Ramos et al. (2012) stated that the muscles of increased activity are the possessors of higher iron levels. It can be inferred that the richest muscles in myoglobin (thigh meat) are more susceptible to lipid oxidation (Kathirvel and Richards, 2012). Besides having a different kind of muscle, the thigh meat is also richer in lipids than the breast meat.

The results that show a lower lipid oxidation of the thigh meat, for the treatments with guava byproduct, can be attributed to the antioxidant effect of phenolic compounds such as flavonoids, as disclosed by Sebastián et al. (2003) for pork. According to Gatellier et al. (2007), chicken meat has low levels of natural antioxidants such as vitamin E, being particularly prone to lipid oxidation and, therefore, the inclusion of guava byproduct in broiler feed can be an alternative to avoid such a problem.

Another important factor to be considered is the $\mathrm{pH}$ of the thigh meat. Although there was no significant difference between the values of experimental treatments, it can be seen that the treatment with the guava byproduct obtained the lowest values. This may be one of the factors that led to a lower lipid oxidation in the meat, which, among other factors, is linked to the development of pathogenic microorganisms, as they have their growth impaired in means with lower $\mathrm{pH}$ values. 


\section{Conclusions}

Guava byproduct can be used as an alternative antioxidant additive in broiler diet at an early stage because it does not depress the productive performance and improves thigh meat quality of broilers.

\section{References}

Amad, A. A.; Wendler, K. R. and Zentek, J. 2013. Effects of a phytogenic feed additive on growth performance, selected blood criteria and jejunal morphology in broiler chickens. Animal Science 25:549-554

Banks, W. J. 1992. Histologia veterinária aplicada. 2 ed. Manole, São Paulo.

Bona, T. D. M. M.; Pickler, L.; Miglino, L. B.; Kuritza, L. N.; Vasconcelos, S. P. and Santin, E. 2012. Óleo essencial de orégano, alecrim, canela e extrato de pimenta no controle de Salmonella, Eimeria e Clostridium em frangos de corte. Pesquisa Veterinária Brasileira 32:411-418.

Bridi, A. M.; Fonseca, N. A. N.; Silva, A. S.; Balarin, M. R. S.; Flaiban, K. K. M. C.; Costantino, C.; Tarsitano, M. A. and Cardoso, T. A. 2012. Indicadores de estresse e qualidade da carne em frangos abatidos pelo método "Halal". Semina: Ciências Agrárias $33: 2451-2460$

Castellini, C.; Magnai, C. and Dal Bosco, A. 2002. Effect of organic production system on broiler carcass and meat quality. Meat Science 60:219-225.

Dibner, J. J. and Richards, J. D. 2004. The digestive system: challenges and opportunities. Journal Applied Poultry Research 13:86-93.

Erickson, H. H. 2006. Fisiologia do exercício. p.277-296. In: Fisiologia dos animais domésticos. 11 ed. Dukes, M. J. S., ed. Guanabara Koogan, Rio de Janeiro.

Faria, P. B.; Bressan, M. C.; Souza, X. R.; Rodrigues, E. C.; Cardoso, G. P. and Gama, L. T. 2009. Composição proximal e qualidade da carne de frangos das linhagens paraíso pedrês e pescoço pelado. Revista Brasileira de Zootecnia 38:2455-2464.

Fletcher, D. L. 2002. Poultry meat quality. World's Poultry Science Journal 58:131-145.

Furlan, R. L.; Macari, M. and Luquetti, B. C. 2004. Como avaliar os efeitos do uso de prebióticos, probióticos e flora de exclusão competitiva. p.6-28. In: Anais do $5^{\circ}$ Simpósio Técnico de Incubação, Matrizes de Corte e Nutrição. Balneário Camboriú.

Gatellier, P.; Gomez, S.; Gigaud, V.; Berri, C. and Bihan-Duval, E. L. 2007. Use of a fluorescence front face technique for measurement of lipid oxidation during refrigerayed storage of chicken meat. Meat Science 76:543-547.

Hashemipour, H.; Kermanshahi, H.; Golian, A.; Raji, A. and Van Krimpen, M. M. 2013. Effect of thymol + carvacrol by next enhance $150 \AA$ on intestinal development of broiler chickens fed CMC containing diet. Iranian Journal of Applied Animal Science 3:567-576.

Iha, M. S.; Migliato, K. F.; Vellosa, J. C. R.; Sacramento, L. V. S.; Pietro, R. C. L. R.; Isaac, V. L. B.; Brunetti, I. L.; Correa, M. A. and Salgado, H. R. N. 2008. Estudo fitoquímico de goiaba (Psidium guajava L.) com potencial antioxidante para o desenvolvimento de formulação fitocosmética. Revista Brasileira de Farmacognosia 18:387-393.

Kathirvel, P. and Richards, M. P. 2012. Effect of a membrane permeable metal chelator on iron and hemoglobin-mediated lipid oxidation in washed fish muscle. Food Research International 48:346-352.
Kuzmuk, N. K.; Swanson, K. S.; Tappenden, K. A.; Schook, L. B. and Fahey Júnior, G.C. 2005. Diet and age affect intestinal morphology and large bowel fermentative end product concentration in senior and young adult dogs. Journal of Nutrition 135:1940-1945.

Lira, R. C.; Rabello, C. B. V.; Ferreira, P. V.; Lana, G. R. Q.; Ludke, J. V. and Dutra Junior, W. M. 2009. Inclusion of guava wastes in feed for broiler chickens. Revista Brasileira de Zootecnia 38:2401-2407.

Longo, F. A.; Menten, J. F. M.; Pedroso, A. A.; Figueiredo, A. N.; Racanicci, A. M. C.; Gaiotto, J. B. and Sorbara, J. O. B. 2005. Diferentes fontes de proteína na dieta pré-incial de frangos de corte. Revista Brasileira de Zootecnia 34:112-122.

Luna, L. G. 1968. Manual of the histologic staining methods of the armed forces institute of pathology. 3rd ed. McGraw Hill, New York.

Macari, M. and Maiorka, A. 2000. Função gastrintestinal e seu impacto no rendimento avícola. p.161-174. In: Anais da Conferência Apinco de Ciência e Tecnologia Avícolas. Fundação Apinco de Ciência e Tecnologia Avícolas, Campinas.

Mendes, A. A. 2001. Jejum pré-abate em frangos de corte. Revista Brasileira de Ciência Avícola 3:199-209.

Nascimento, R. J.; Araújo, C. R. and Melo, E. A. 2010. Atividade antioxidante de extratos de resíduo agroindustrial de goiaba (Psidium Guajava L.). Alimentação e Nutrição 21:209-216.

Oliveira, F. R.; Andrade, B. C.; Pires, A. V.; Mognato, J. C.; Carvalho, R. M. S.; Santos Júnior, M. A. and Mattioli, C. C. 2015. Jejum alimentar e qualidade da carne de frango de corte tipo caipira. Revista Brasileira de Saúde e Produção Animal 16:667-677.

Ramos, A.; Cabrera, M. C. and Sadoun, A. 2012. Bioaccessibility of $\mathrm{Se}, \mathrm{Cu}, \mathrm{Zn}, \mathrm{Mn}$ and $\mathrm{Fe}$, and heme iron content in unaged and aged meat of Hereford and Braford steers fed pasture. Meat Science 91:116-124.

Rodrigues, K. F.; Rodrigues, P. B.; Bressan, M. C.; Nagata, A. K.; Silva, J. H. V. and Silva, E. L. 2008. Qualidade da carne de peito de frangos de corte recebendo rações com diferentes relações lisina digestível:proteína bruta. Revista Brasileira de Zootecnia 37:1023-1028.

Rostagno, H. S.; Albino, L. F. T.; Donzele, J. L; Gomes, P. C.; Oliveira, R. F.; Lopes, D. C.; Ferreira, A. S. and Barreto, S. L. T. 2011. Tabelas brasileiras para aves e suínos: composição de alimentos e exigências nutricionais. 3 ed. UFV, Viçosa, MG.

Sebastián, M.; Granizo, J. and Navarro, M. 2003. Antioxidantes biomoleculares en nutrición animal - novedades y aplicaciones. p.45-49. In: Anais do $2^{\circ}$ Seminário Internacional sobre Produção, Mercado e Qualidade de Carne de Suínos. AVESUI, Florianópolis.

Silva, M. A.; Pessotti, B. M. S.; Zanini, S. F.; Colnago, G. L.; Nunes, L. C.; Rodrigues, M. R. A. and Ferreira, L. 2010. Óleo de aroeiravermelha sobre o desempenho e a morfometria intestinal de frangos de corte. Ciência Rural 40:2151-2156.

Sousa, M. S. B.; Vieira, L. M.; Silva, M. J. M. and Lima, A. 2011. Caracterização nutricional e compostos antioxidantes em resíduos de polpas de frutas tropicais. Ciência e Agrotecnologia $35: 554-559$.

Souza, X. R.; Bressan, M. C.; Pérez, J. R. O.; Faria, P. B.; Vieira, J. O. and Kabeya, D. M. 2004. Efeitos do grupo genético, sexo e peso ao abate sobre as propriedades físico-químicas da carne de cordeiros em crescimento. Ciência e Tecnologia dos Alimentos 24:543-549.

Tarladgis, B. G.; Watts, B. M. and Younathan, M. T. 1960. A distillation method for the quantitative determination of malonaldehyde in rancid foods. The Journal of the American al Chemists Society 37:44-48.

Uni, Z.; Noy, Y. and Sklan, D. 1995. Post-hatch changes in morphology and function of the small intestine in heavy and light strain chicks. Poultry Science 74:1622-1629. 
Van Laack, R. L.; Liu, C. H.; Smith, M. O. and Loyeday, H. D. 2000. Characteristics of pale, soft, exudative broiler breast meat. Poultry Science 79:1057-1061.

Warris, P. D. 2010. Meat science: an introductory text. 2th ed. CABI Pub. Inc., New York.
Yi, F. G.; Allee, G. L.; Frank, J. W.; Spencer, J. D. and Touchette, K. J. 2005. Impact of gand Oasis hatchling supplement on growth performance, small intestinal morphology, and immune response of broilers vaccinated and challenged with Eimera maxima. Poultry Science 84:283-293. 